\title{
GENUS GULO.-STORR.
}

\author{
DENTAL FORMULA. \\ Incisive $\frac{6}{6} ;$ Canine $\frac{1-1}{1-1} ;$ Molar $\frac{5-5}{6-6}=38$.
}

The three first molars in the upper, and the four first in the lower jaw, small ; succeeded by a larger carnivorous or trenchant tooth, and a small tuberculous tooth at the back.

In the upper jaw the three first molars are uni-cuspidateous, and may be called false-carnivorous teeth, increasing successively in size; the following or carnivorous tooth is large and strong, furnished with two points on the inner side, and a trenchant edge in front; the last tooth is small, and tuberculous or flattish.

In the lower jaw the first four molars are false, each presenting only one point or edge; the fifth is long and large, with two trenchant points; the last molar is nearly flat. All the teeth touch each other successively. (Cuv.)

Head, of moderate length; body, long; legs, short; tail, bushy ; feet, with five deeply divided toes, terminated by long curved nails.

No glandular pouch in some of the species, but a simple fold beneath the tail.

Habits, carnivorous and nocturnal.

The generic name is derived from the Latin gulo, a glutton.

Four species of this genus have been described; one existing in the Arctic regions of both continents, two in South America, and one in Africa.

\section{G U L O L U S C U S . - Linn.}

The Wolverene, or Glutton.

\section{PLATE XXVI.}

G. subniger; fasciâ subalbida utrinque a humero per ilia producta, fasciis supra coxas se jungentibus; caudâ pilis longis hirsutâ. 


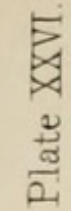

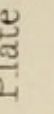

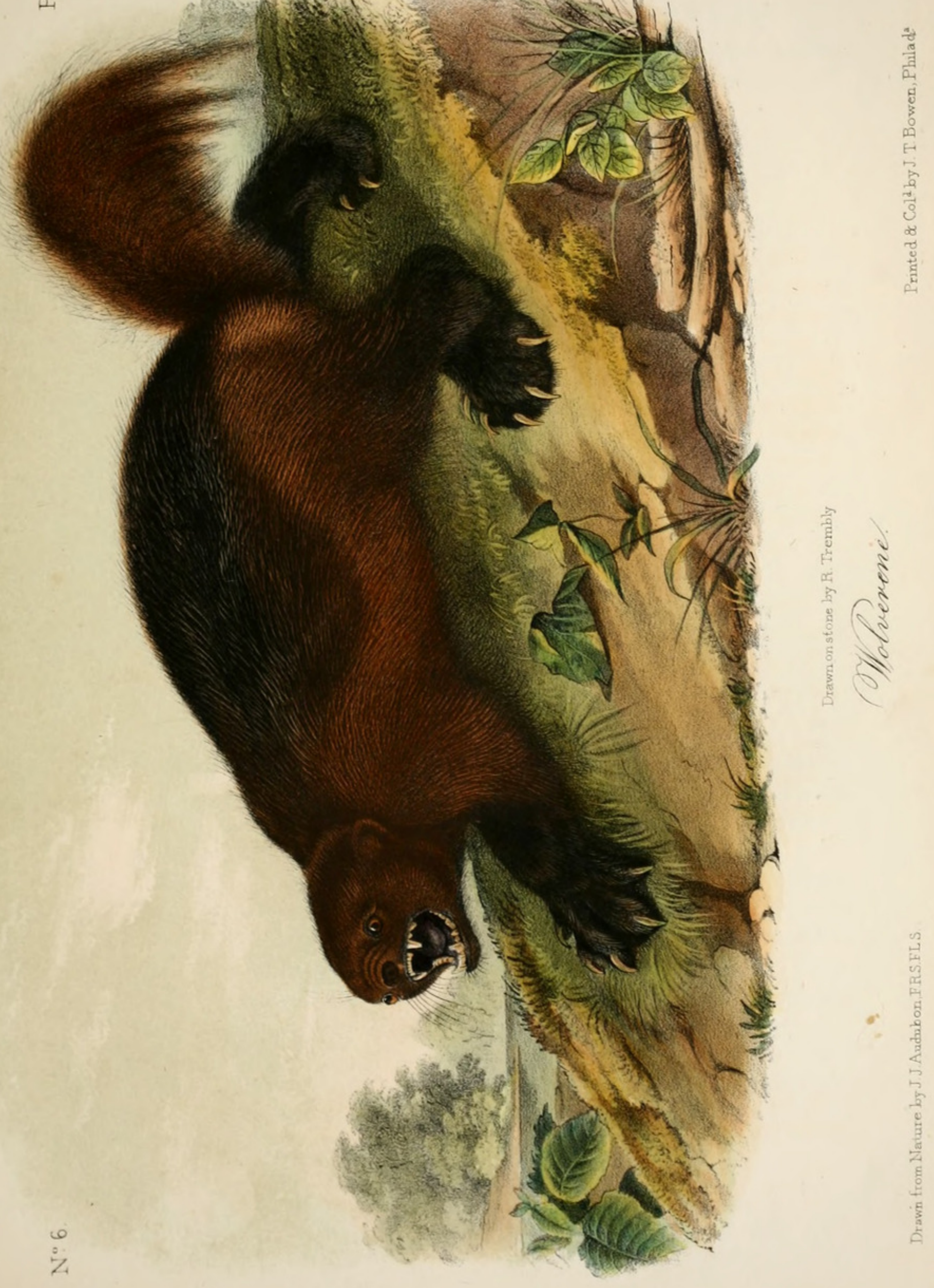



CHARACTERS.

Dark-brown, passing into black, above; a pale band on each side, running from the shoulders around the flanks, and uniting on the hips; tail, with long bushy hairs.

SYNONYMES.

Mustela Gulo, Linn., Syst. Nat., 12th edit.

Ursus Luscus, Linn., Syst., Nat., 12th edit.

Ursus Gulo, Pallas, do., Schreber, Säugeth., p. 525.

“ " $\quad$ F. Cuv., in Dict. des Sc. Nat., 19th edit., p. 79, c. fig.

Quickнатсн or Wolverine, Ellis, Voy. Hudson's Bay, p. 42.

Ursus Freti Hudsonis, Briss, Quad., p. 188.

Wolvering, Cartwright's Journal, vol. ii., p. 407.

Wolverine, Pennant's Hist. Quad., vol. ii., p. 8, t. 8, Hearne's Journey, p. 372.

Gulo Arcticus, var. A. Glouton Wolverine., Desm., Mamm., p. 174.

Gulo Luscus, (Capt.) Sabine, supp. Parry's 1st Voyage, p. 184.

" " Sabine, (Mr.) Franklin's 1st Journey, p. 650.

“ “ $\quad$ " Richardson's Appendix Parry's 2d Voyage, p. 292.

“ “ $\quad$ Fischer's Mammalium, p. 154.

The Glutton, Buffon, vol. vii., p. 274, pl. 243.

Ursus Gulo, Shaw's Gen. Zool., vol. i., p. 46.

Golo Vulgaris, Griffith's Animal Kingdom, sp. 331.

Gulo Wolverine, Griffith's Animal Kingdom, sp. 332.

Gulo Luscus, Rich., F. B. A., p. 41.

“ $\quad$ " Capt. Ross, Expedition, p. 8.

Carcajou, French Canadians; Quickhatch, English residents.

DESCRIPTION.

Head, of moderate size, broad on the hinder part, much arched, rounded on all sides ; nose, obtuse, naked ; eyes small ; ears, short, broad, rounded, and partially hidden by the surrounding fur. The whole head bears a strong resemblance to that of some of the varieties of the dog.

Body, very long, stout, and compactly made; back, arched; the whole form indicating strength without much activity. The Wolverene is covered with a very thick coat of two distinct kinds of hair. The inner fur, soft and short, scarcely an inch long; the intermixed hairs, numerous, rigid, smooth, and four inches long; giving the animal the appearance of some shaggy dog.

Legs, short and stout; feet, broad, clothed on the under surface with a compact mass of woolly hair. Toes, distinct, and armed with five strong, rounded, and pretty sharp claws. The tracks made in the snow by this species are large, and not very unlike those of the bear. There are five 
tubercles on the soles of the fore-feet, and four on the hind-feet; no tubercle on the heel.

The tail is rather short, hangs low, and is covered with pendulous hairs. "There are two secretory organs about the size of a walnut, from which it discharges a fluid of a yellowish-brown colour and of the consistence of honey, by the rectum, when hard pressed by its enemies."Ross.

\section{COLOUR.}

Under fur, deep chesnut-brown, a shade lighter near the roots; the longer hairs are blackish-brown throughout their whole length, the hair having very much the appearance of that of the bear. Eyes, nose, and whiskers, black; a pale reddish-brown band commences behind the shoulder, and running along the flanks, turns up on the hip, and unites on the rump with similar markings on the opposite side. There is a brownish-white band across the forehead running from ear to ear. On the sides of the neck there are tufts of white hair extending nearly in a circle from the inside of the legs around the chest. Legs and tail, brown ish-black; claws, dark-brown. The colour varies greatly in different specimens, and although there is a strong general resemblance among all we have examined, we are not surprised that attempts have been made from these varieties to multiply the species. There are however no permanent varieties among the many specimens we have examined. The peculiar lateral band, although it exists in all, differs a few shades in colour. In some specimens it is of a chesnut colour, in others light ferruginous, and in a few cases ash-coloured. We find these differences of colour existing in both continents, and not confined to either. We have never seen a specimen of a Wolverene as light in colour as that to which Linneus gave the specific name of luscus, and we regard it as a mere accidental variety. We have found American specimens obtained in the Polar regions fully as black as those from Russia.

DIMENSIONS.

Recent specimen, obtained in Rensselaer county, N. Y.

$\begin{array}{llllllll}\text { From point of nose to root of tail } & - & - & 2 & 9 & 0 \\ \text { Tail (vertebræ) } & - & - & - & - & 0 & 8 & 0 \\ \begin{array}{l}\text { Height to shoulder - } \\ \text { " } \quad-\end{array}- & - & - & 1 & 0 & 0 \\ \text { Length ear, posteriorly hair on body } & - & - & - & - & 0 & 1 & 6 \\ \begin{array}{l}\text { From heels to point of nails } \\ \text { Breadth of hind-foot }\end{array} & - & - & - & - & 0 & 5 & 0 \\ \end{array}$


Specimen from which our figure was made.

$\begin{array}{lllllllll} & & & \text { Feet. } & \text { Inches. } & \text { Lines. } \\ \text { From point of nose to root of tail } & - & - & 2 & 6 & 0 \\ \text { Tail (vertebræ) } & - & - & - & - & - & 0 & 6 & 0 \\ \text { Tail, including fur } & - & - & - & - & - & 0 & 10 & 0 \\ \text { Height of ear - } & - & - & - & - & - & 0 & 1 & 4\end{array}$

HABITS.

The Wolverene, or Glutton as he is generally called, is one of the animals whose history comes down to us blended with the superstitions of the old writers. Errors when once received and published, especially if they possess the charm of great singularity or are connected with tales of wonder, become fastened on the mind by early reading and the impressions formed in youth, until we are familiarized with their extravagance, and we at length regret to find ideas (however incorrect) adopted in early life, not realized by the sober inquiries and investigations of maturer years.

The Wolverene, confined almost exclusively to Polar regions, where men have enjoyed few advantages of education and hence have imbibed without much reflection the errors, extravagances and inventions of hunters and trappers, has been represented as an animal possessing extraordinary strength, agility, and cunning, and as being proverbially one of the greatest gormandizers among the "brutes." Olaus Magnus tells us that "it is wont when it has found the carcass of some large beast to eat until its belly is distended like a drum, when it rids itself of its load by squeezing its body betwixt two trees growing near together, and again returning to its repast, soon requires to have recourse to the same means of relief." It is even said to throw down the moss which the reindeer is fond of, and that the Arctic fox is its jackal or provider. Buffon, in his first description of this animal, seems to have adopted the errors and superstitions of Olaus Magnus, Schoeffer, Gesner, and the early travellers into Sweden and Lapland. He says of this animal, (vol. vii., p. 277,) "the defect of nimbleness he supplies with cunning: he lies in wait for animals as they pass, he climbs upon trees in order to dart upon his prey and seize it with advantage; he throws himself down upon elks and reindeer, and fixes so firmly on their bodies with his claws and teeth that nothing can remove him. In vain do the poor victims fly and rub themselves against trees; the enemy, attached to the crupper or neck, continues to suck their blood, to enlarge the wound, and to devour them gradually and with equal voracity, till they fall down."

"More insatiable and rapacious than the wolf, if endowed with equal 
agility the Glutton would destroy all the other animals; but he moves so heavily that the only animal he is able to overtake in the course is the beaver, whose cabins he sometimes attacks, and devours the whole unless they quickly take to the water, for the beaver outstrips him in swimming. When he perceives that his prey has escaped, he seizes the fishes; and when he can find no living creature to destroy, he goes in quest of the dead, whom he digs up from their graves and devours with avidity."

Even the intelligent Gmelin, who revised and made considerable additions to the great work of Linnaus, on a visit to the North of Europe imbibed many of the notions of the Siberian hunters, and informs us, without however giving full credence to the account, that the Wolverene "watches large animals like a robber, or surprises them when asleep," that "he prefers the reindeer," and that "after having darted down from a tree like an arrow upon the animal, he sinks his teeth into its body and gnaws the flesh till it expires; after which he devours it at his ease, and swallows both the hair and skin."

However, although Buffon in his earlier history of the species adopted and published the errors of previous writers, he subsequently corrected them and gave in a supplementary chapter not only a tolerable figure but a true history. He received a Wolverene alive from the northern part of Russia, and preserved it for more than eighteen months at Paris. And when the Count was thus enabled to examine into its habits, as they were developed from day to day, he found them of a very ordinary character, and it was discovered to be an animal possessing no very striking peculiarities. He informs us, "He was so tame that he discovered no ferocity and did not injure any person. His voracity has been as much exaggerated as his cruelty: he indeed ate a great deal, but when deprived of food he was not importunate."

"The animal is pretty mild; he avoids water, and dreads horses and men dressed in black. He moves by a kind of leap, and eats pretty voraciously. After taking a full meal he covers himself in the cage with straw. When drinking he laps like a dog. He utters no cry. After drinking, he throws the remainder of the water on his belly with his paws. He is almost perpetually in motion. If allowed, he would devour more than four pounds of flesh in a day; he eats no bread, and devours his food so voraciously, and almost without chewing, that he is apt to choke himself."

We have seen this species in a state of confinement in Europe; the specimens came, we were informed, from the north of that continent. In Denmark, a keeper of a small caravan of animals allowed us the privilege of examining a Wolverene which he had exhibited for two years. 
We took him out of his eage; he was very gentle, opened his mouth to enable us to examine his teeth, and buried his head in our lap whilst we admired his long claws and felt his woolly feet; he seemed pleased to escape from the confinement of the cage, ran round us in short circles, and made awkward attempts to play with and caress us, which reminded us very much of the habit of the American black bear. He had been taught to sit on his haunches and hold in his mouth a German pipe. We observed he was somewhat averse to the light of the sun, keeping his eyes half closed when exposed to its rays. The keeper informed us that he suffered a good deal from the heat in warm weather, that he drank water freely and ate meat voraciously, but consumed more in winter than in summer. There was in the same cage a marmot from the Alps, (Arctomys marmota,) to which the Wolverene seemed much attached. When returned to his cage, he rolled himself up like a ball, his long shaggy hairs so completely covering his limbs that he presented the appearance of a bear-skin rolled up into a bundle.

In the United States the Wolverene has always existed very sparingly, and only in the Northern districts. About thirty-five years ago, we saw in the possession of a country merchant in Lansingburg, New-York, three skins of this species, that had as we were informed been obtained on the Green Mountains of Vermont; about the same time we obtained a specimen in Rensselaer county, near the banks of the Hoosack river. While hunting the Northern hare, immediately after a heavy fall of snow, we unexpectedly came upon the track of an animal which at the time we supposed to be that of a bear, a species which even then was scarcely known in that portion of the country, (which was already pretty thickly settled.) We followed the broad trail over the hills and through the devious windings of the forest for about five miles, till within sight of a ledge of rocks on the banks of the Hoosack river, when, as we found the night approaching, we were reluctantly compelled to give up the pursuit for that day, intending to resume it on the following morning. It snowed incessantly for two days afterwards, and believing that the bear had retired to his winter retreat, we concluded that the chance of adding it to our collection had passed by. Some weeks afterwards a favourite servant who was always anxious to aid us in our pursuits, and who not only knew many quadrupeds and birds, but was acquainted with many of their habits, informed us that he had on a previous day seen severa. tracks similar to those we had described, crossing a new road cut through the forest. As early on the following morning as we could see a track in the snow, we were fully accoutred, and with a gun and a pair of choice hounds, started on what we conceived our second bear-hunt. Before 
reaching the spot where the tracks had been observed, however, we met a fresh trail of the previous night, and pursued it without loss of time. The animal had joined some foxes which were feeding on a dead horse not a hundred yards from a log cabin in the forest, and after having satiated itself with this delicate food, made directly for the Hoosack

* river, pursuing the same course along which we had formerly traced it. To our surprise it did not cross the river, now firmly bound with ice, but retired to its burrow, which was not far from the place where we had a few weeks before abandoned the pursuit of it. The hounds had not once broke into full cry upon the track, but no sooner had they arrived at the mouth of the burrow than they rushed into the large opening between the rocks, and commenced a furious attack on the animal within. This lasted but for a few moments, and they came out as quickly as they had entered. They showed some evidence of having been exposed to sharp claws and teeth, and although they had been only a moment engaged in battle, had no disposition to renew it. No effort of ours could induce them to re-enter the cavern, whilst their furious barking at the mouth of the hole was answered by a growl from within. The animal, although not ten feet from the entrance, could not be easily reached with a stick on account of his having retreated behind an angle in the chasm. As we felt no particular disposition to imitate the exploits of Colonel Putnam in his rencontre with the wolf, we reluctantly concluded to trudge homeward through the snow, a distance of five miles, to obtain assistance. On taking another survey of the place, however, we conceived it possible to effect an opening on one of its sides. This was after great labour accomplished by prying away some heavy fragments of the rock. The animal could now be reached with a pole, and seemed very much irritated, growling and snapping at the stick, which he once succeeded in tearing from our hand, all the while emitting a strong and very offensive musky smell. He was finally shot. What was our surprise and pleasure on discovering that we had, not a bear, but what was more valuable to us, a new species of quadruped, as we believed it to be. It was six months before we were enabled, by consulting a copy of Buffon, to discover our mistake and ascertain that our highly prized specimen was the Glutton, of which we had read such marvellous tales in the school-books.

In some of the figures that we have seen of the Wolverene, or Glutton, he is represented as touching the ground to the full extent of his heel, and in several of the descriptions this habit is also assigned to him. Our notes in reference to this point were made in early life, and it is possible that we may have laboured under a mistake; but we are confident, from 
our own observation, that the animal treads upon its hind-feet in the manner of the dog, that the impression of the tarsus or heel can only be observed in deep snow, and that in its ordinary walk on the ground the heel seldom touches the earth. We made no note in regard to the living Wolverene we saw in Europe, but are under an impression that its method of walking was similar to that stated above. There is another peculiarity in the tracks of the animal: in walking, the feet do not cross or approach each other in the manner of the feet of a fox or wolf, but make a double track in the snow, similar in this respect to that of the skunk.

There was a large nest of dried leaves in the cavern, which had evidently been a place of resort for the Wolverene we have been speaking of, during the whole winter, as its tracks from every direction led to the spot. It had laid up no winter store, and evidently depended on its nightly excursions for a supply of food. It had however fared well, for it was very fat.

It has been asserted that the Wolverene is a great destroyer of beavers: but we are inclined to think that this can scarcely be the case, unless it be in summer, when the beaver is often found some distance from the water. In such cases we presume that the Wolverene, although not swift of foot, could easily overtake that aquatic animal. But, should he in winter attempt to break open the frozen mud-walls of the beaver-huts, which would be a very difficult task, this would only have the effect of driving the occupants into their natural element, the water, where their hungry pursuer could not follow them. The statement of his expertness in swimming, diving, and catching fish, we believe to be apocryphal.

We are inclined to adopt the views of Richardson in regard to the Wolverene, that it feeds chiefly on the carcasses of beasts that have been killed by accident. "It also devours meadow-mice, marmots, and other rodentia, and occasionally destroys disabled quadrupeds of a larger size."

That it seizes on deer or large game by pouncing on them, is incredible; it neither possesses the agility nor the strength to accomplish this feat. This habit has also been ascribed to the Canada lynx as well as to the Bay lynx; we do not think it applies to either. That the Wolverene occasionally captures the grouse that have plunged into the fresh snow as a protection from the cold, is probable.

Richardson observes that he saw one chasing an American hare, which was at the same time harassed by a snowy owl. The speed of the hare however is such that it has not much to fear from the persevering but 
slow progress of the Wolverene; and the one seen by Richardson, in his efforts to catch the tempting game must have been prompted by a longing desire after hare's flesh, rather than by any confidence in his ability to overtake the animal.

All Northern travellers and writers on the natural history of the Arctic regions, Ellis, Pennant, Hearne, Parry, Franklin, Richardson, \&c., speak of the indomitable perseverance of the Wolverene in following the footsteps of the trappers, in order to obtain the bait, or take from the traps the Arctic fox, the marten, beaver, or any other animal that may be caught in them. They demolish the houses built around the dead-falls, in order to obtain the bait, and tear up the captured animals apparently from a spirit of wanton destructiveness. Hearne (p. 373) gives an account of their amazing strength, one of them having overset the greatest part of a large pile of wood, measuring upwards of seventy yards round, to get at some provisions that had been hid there. He saw another take possession of a deer that an Indian had killed, and though the Indian advanced within twenty yards he would not relinquish his claims to it, but suffered himself to be shot, standing on the deer. Hearne farther states, "they commit vast depredations on the foxes during the summer, while the young ones are small; their quick scent directs them to their den, and if the entrance be too small, their strength enables them to widen it, and go in and kill the mother and all her cubs; in fact they are the most destructive animals in this country."

Capt. J. C. Ross, R. N., F. R. S., who gave an interesting account of the animals seen in the memorable expedition of Sir Joнn Ross, relates the following anecdote of this species:- "In the middle of winter, two or three months before we abandoned the ship, we were one day surprised by a visit from a Wolverene, which, hard pressed by hunger, had climbed the snow wall that surrounded our vessel, and came boldly on deck where our crew were walking for exercise. Undismayed at the presence of twelve or fourteen men, he seized upon a canister that had some meat in it, and was in so ravenous a state that whilst busily engaged at his feast he suffered me to pass a noose over his head, by which he was immediately secured and strangled."

The Wolverene is at all times very suspicious of traps, and is seldom taken in the log-traps set for the marten and Arctic fox; the usual mode in which it is obtained is by steel-traps, which must be set with great caution and concealed with much art.

Captain CARTwRIghT in his journal speaks of having caught all he obtained at Labrador in this manner, and we have seen several skins giving evidence that the animals had been taken by the foot. 
Captain Cartwright (see Journal, vol. ii., p. 407) records an instance of strength and cunning in this species that we cannot pass by in giving its history; we will use his own words. "In coming to the foot of Table Hill I crossed the track of a Wolvering with one of Mr. Callinghan's traps on his foot; the foxes had followed his bleeding track. As this beast went through the thick of the woods, under the north side of the hill, where the snow was so deep and light that it was with the greatest difficulty I could follow him even in Indian rackets, I was quite puzzled to know how he had contrived to prevent the trap from catching hold of the branches of the trees or sinking in the snow. But on coming up with him I discovered how he had managed; for after making an attempt to fly at me, he took the trap in his mouth and ran upon three legs. These creatures are surprisingly strong in proportion to their size; this weighed only twenty-six pounds and the trap eight; yet including all the turns he had taken he had carried it six miles."

The Wolverene produces young but once a year, from two to four at a litter. Richardson says the cubs are covered with a downy fur of a pale or cream colour. The fur of the Wolverene resembling that of the bear, is much used for muffs, and when several skins are sewed together makes a beautiful sleigh-robe.

GEOGRAPHICAL DISTRIBUTION.

The Wolverene exists in the north of both continents. On the Eastern continent it inhabits the most northern parts of Europe and Asia, occurring in Sweden, Norway, Lapland, and Siberia, as well as in some of the Alpine regions, and in the forests of Poland and Courland. In North America it is found throughout the whole of the Arctic circle. They were caught to the number of ten or twelve every winter by Capt. CArtwright in Labrador. It exists at Davis' Straits, and has been traced across the continent to the shores of the Pacific. It is found on the Russian islands of Alaska. Richardson remarks, "It even visits the islands of the Polar sea, its bones having been found in Melville Island, nearly in latitude $75^{\circ}$. It occurs in Canada, although diminishing in numbers the farther we proceed southerly. We have seen specimens procured at Newfoundland, and have heard of its existence, although very sparingly, in Maine. Professor Emmons, (Dekax, Nat. Hist. of New-York,) states that it still exists in the Hoosack Mountains of Massachusetts. We examined a specimen obtained in Jefferson county, near Sackett's Harbour, N. Y., in 1827, and in 1810 we obtained a specimen in Rensselaer county, latitude $42^{\circ} 46^{\prime}$; we have never heard of its existence farther south. 
This species has been arranged by different authors under several genera. Linneus placed it under both Mustella and Ursus. Storr established for it the genus Gulo, which was formed from the specific name, as it had been called Ursus Gulo, by Linneus. Storn's generic name has been since adopted by Cuvier and other modern naturalists. Gray named it Grisonia. Linneus is notwithstanding entitled to the specific name, although this is the result of an error into which he was led in this manner: EDwARDs had made a figure from a living specimen imported from America. It was a strongly marked variety, with much white on its forehead, sides, and neck. Linneus regarding it as a new species, described it as such. In seeking for some name by which to designate it, he observed that it had lost one eye, and it is supposed applied the trivial name "luscus," one-eyed, to the animal, merely on account of the above accidental blemish.

The vulgar names Glutton, Carcajou, \&c., have given rise to much confusion in regard to the habits of the species.

The name Glutton induced many ancient authors to ascribe to it an appetite of extravagant voraciousness.

Carcajou appears to be some Indian name adopted by the French, and this name has evidently been applied to different species of animals. Charlevorx, in his Voyage to America, vol. i., p. 201, speaks of the "carcajou or quincajou, a kind of cat, with a tail so long that he twists it several times round his body, and with a skin of a brownish red." $\mathrm{He}$ then refers to his climbing a tree, where after two foxes have driven the elk under the tree, the cat being on the watch pounces on it in the manner ascribed to the Wolverene. Here he evidently alludes to the cougar, as his long tail and colour apply to no other animal in our country. Lawson refers the same singular habit to the wild cat of Carolina; he says, (p. 118,) " the wild cat takes most of his prey by surprise, getting up the trees which they pass by or under, and thence leaping directly upon them. Thus he takes deer, which he cannot catch by running, and fastens his teeth into their shoulders. They run with him till they fall down for want of strength and become a prey to the enemy."

In the last work published on American Quadrupeds, Lawson is quoted as authority for the former existence of the Wolverene in Carolina, and a reference is also made to a plate of that species. On looking over the work of Lawson, (London, 1709,) we find that no mention is made of the Wolverene, and no plate of the animal is given. We have supposed it 
possible that the author of the "Natural History of New-York" might have intended to refer to CATESBX; but the latter gave no plate of the species, and only noticed it as existing in the very northern parts of America. We feel confident that the geographical range of the Wolverene has never extended to Carolina, that it existed only as a straggler in the northern portion of the Middle States, and that it is now, and ever has been, almost entirely confined to the Northern regions. 


\section{$2 \mathrm{BHL}$ Biodiversity Heritage Library}

Audubon, John James and Bachman, John. 1851. "Gulo Luscus, Wolverene or Glutton, [PI. XXVI]." The quadrupeds of North America 1, 202-213. https://doi.org/10.5962/p.322459.

View This Item Online: https://www.biodiversitylibrary.org/item/108513

DOI: https://doi.org/10.5962/p.322459

Permalink: https://www.biodiversitylibrary.org/partpdf/322459

\section{Holding Institution}

Duke University Libraries (archive.org)

\section{Sponsored by}

Duke University Libraries

\section{Copyright \& Reuse}

Copyright Status: Not provided. Contact Holding Institution to verify copyright status.

This document was created from content at the Biodiversity Heritage Library, the world's largest open access digital library for biodiversity literature and archives. Visit BHL at https://www.biodiversitylibrary.org. 